\title{
An Empirical Analysis of the Domestic Trends in Tea Imports of India
}

\author{
M. Saravanakumar ${ }^{1}$, A.V.Chinnasamy ${ }^{2}$ \\ ${ }^{I}$ (Ph.D., Research Scholar, Department of Economics, Karpagam University, Coimbatore, India-641 021) \\ ${ }^{2}$ (Assistant Professor, Department of Economics, R.D. Government Arts College, Sivagangai, India-630 561)
}

\begin{abstract}
Large scale import of tea to India was witnessed ever since the removal of quantitative restrictions in 2001. Assam is the single largest tea growing state accounting for half of the country's total production. Today tea is grown on tea estates and 70 percentage of the tea we drink is from Sri Lanka, India, Indonesia, Kenya, Argentina and China. Majority of these imports are through duty free route for subsequently re-exports. Time series analysis is used to compute the domestic trends in tea imports of India. World tea imports for consumption was estimated at 1609.7 M.Kgs in 2011 compared to 1613.6 M.Kgs in 2010, a decline of 3.9 M.Kgs. The decline in world imports was led by Egypt which reported $11.3 \mathrm{M}$.Kgs decrease in imports at 81.7 M.Kgs. During 2011, the quantum of imports in India has declined to 18.6 M.Kgs compared to $20.0 \mathrm{M}$.Kgs, a decline of 1.4 M.Kgs. and in 2011, Nepal and Kenya turned to be the major source of the higher unit value of imports from these two countries.
\end{abstract}

Keywords: Tea Imports, Fluctuation, Price, Production, Time Series Analysis.

\section{Introduction Of Tea}

Tea is nearly 5,000 years old and was discovered by Chinese Emperor Shen Nung in 2737 B.C., brought fortune to England as well as loss of her colonies in the New World. When dried leaves blew into his cup of hot water, the beverage he discovered would cause sensations around the world. During this time, water was always boiled for hygienic reasons. The pleasant aroma and refreshing taste enchanted him and soon everyone in the realm was drinking tea. In the 1880 's, Tea is a natural source of the amino acid theanine, methylxanthines such as caffeine and theobromine and polyphenolic antioxidant catechins. It has almost no carbohydrates, fat or protein. It has a cooling, slightly bitter and astringent flavour.

India is the world's second largest producers and the biggest consumer of the beverages, with 13,000 gardens and a workforce of more than 2 million people. Assam is the single largest tea growing state accounting for half of the country's total production. Today tea is grown on tea estates and 70 percentage of the tea we drink is from Sri Lanka, India, Indonesia, Kenya, Argentina and China. Tea is a beverage made by steeping processed leaves and our realm gets more foreign exchange while exporting tea. In the early 1920s, world exports of tea were around 310,000 metric tons per annum. Of this, 75 percentages came from British plantations in India and Ceylon and 9 percentages from Dutch producers in the Netherlands East Indies. During this time, the United Kingdom absorbed 60 percentage of total world tea export.

\section{Origin Of Tea In India}

In 1788, the British botanist Joseph Banks reported to the British East India Company that the climate in certain British controlled parts of North East India was ideal for tea growing started cultivation around the town of Darjeeling in the foothills of the Himalayas in the mid-1850s. In the late 1830s, the tea plant was growing wild in the jungles of northeast Assam. In 1823 and 1831, Robert Bruce and his brother Charles, an employee of the East India Company, confirmed that the tea plant was indeed a native of the Assam area and sent seeds and specimen plants to officials at the newly established Botanical Gardens in Calcutta.

In 1832, Dr.Christie was the first to experiment with the growing of tea plants in South India and some of his plants were distributed to various parts of the Nilgiris hills for trial. In 1834, a few plants grown from the seeds brought from china were again planted in these hills. By 1857, between 60 and 70 acres were under tea and whereas the China variety of the tea plant had not liked the condition in Assam, here at elevations of 2500 to 6000 feet, it grew well the company pushed on into Terai, Dooars and even into the remote Kangra valley, 800 miles west of Darjeeling. The earliest record of commercial planting in Kerala was in peermade during 1875. The development of Kannan Devan Hills by James Finlay and Co. In 1878 with tea as an exclusive crop, is a landmark in the history of tea planting in this part of the country. 


\section{Significance Of Imports}

The term import is derived from the conceptual meaning as the goods and services into the port of a country. The buyer of such goods and services is referred to an "importer" who is based in the country of import where the overseas based seller is referred to as an "exporter". Thus an import is any good (e.g. a commodity) or service brought in from one country to another country in a legitimate fashion, typically for use in trade. It is a good that is brought in from another country for sale. Imported goods or services are provided to domestic consumers by foreign producers. An import in the receiving country is an export to the sending country.

\subsection{Pattern of imports}

Imports have been classified into Bulk Import and Non-bulk Imports of foreign trade.

There are two basic types of import:

- Industrial and consumer goods.

- Intermediate goods and services

\subsubsection{Bulk Imports of India's Foreign Trade}

- Petroleum, crude and products.

- Bulk consumption goods which comprise of cereals and pulses, edible oils and sugar.

- Other bulk items comprising of fertilizers, non -ferrous metals, paper and paper boards, rubber, pulp and waste paper, metallic ores, iron and steel.

\subsubsection{Non - Bulk Imports of India's Foreign Trade}

- Capital goods which include metals, machine tools, electrical and non-electrical machinery, transport equipment and project goods.

- Main export-related items consists of pearls, precious and semi-precious stones, organic and inorganic chemicals, textile, yarn and fabrics, cashew nuts

- Others include artificial resins and plastic materials, professional and scientific instruments, coal and coke, chemicals - medicinal and pharmaceutical products, non-metallic mineral manufactures etc.

\section{Trends Of Imports}

The imports of food grains were necessitated by the partition of the country and the growing demand for food for the rising population. The average annual imports of food grains during the First Plan which were about Rs. 120 crores rose to Rs.161crores in the Second Plan. But during 1992-93 they again rose to Rs. 1,240 crores. Even during 2006-07, food grains worth Rs. 5,996 crores were imported. In the year 2008-09 imports were just Rs. 216 crores.

Machinery includes electrical and non-electrical equipment as also locomotives. In a country which is rapidly industrializing the economy. Imports of machinery are bound to increase. During 1960-61 the average annual import of machinery which was about Rs.260 crores. Machinery import further went up to Rs. 2,26,137 crores during 2008-09. The increasing import of machinery is an indicator of our growing industrialization.

Imports of POL are also on the increase. India is short in the supply of mineral oils, especially petroleum. On account of the sharp increase in the prices of crude announced by the organization of petroleum Exporting Countries, during 1980-81 import of petroleum, oil and lubricants rose to very high level of Rs. 5,264 crores. During 2008-09 import of POL reached a record level of Rs.4,19,946 crores i.e. about 30.6 percent of total imports.

India imports iron and steel and also some non-ferrous metals. The annual average imports of ferrous and non-ferrous metals which were about Rs. 54 crores during First Plan. During 2008-09, metals worth Rs. $1,70,200$ crores were imported accounting for 12.4 percentage of total imports.

Increase in the imports of Chemical, drugs and medicines. The annual average of these was about Rs. 55 crores during the Third Plan. They rose further to Rs. 9,614 crores during 2008-09.

The import of pearls and precious stones averaged Rs. 417 crores during 1980-81. Part of these imports serves as raw materials for the handicrafts export industry. It may be noted that the export of pearls and precious stones were of the order of Rs. 76,130 crores during 2008-09.

Adoption of new strategy in Indian agriculture, the imports of fertilizers were stepped up, with a sharp increase in the international prices of fertilizers, fertilizers imports rose to Rs. 818 crores in 2000-01. As a consequence of liberalization, fertilizer imports were of the order of Rs. 59,567 crores during 2008-09. 


\section{Objectives}

The main objective is to analyses the domestic trends in tea imports of India.

\section{Collection Of Data}

In order to analyses the domestic trends in tea imports of India, secondary data were collected from tea statistics.

\section{Problems Of The Study}

Fluctuations of the domestic trends in tea imports of India

\section{Time Series Analysis}

A time series is the data on any variable recorded over a constant time interval. The period of data recording may be an hour, a day, a week, a month or a year, depending on the type of event the data refer. Thus, a time series consists of four components. a) Secular variations/secular trend b) Cyclical variations c) Seasonal variations and d) Irregular variations.

A time series graph reveals the characteristic features of the pattern of variations in the time series. Even a casual look at the graph is able to show the upward or downward direction the movement in the time series tends to follow over a long period of time. The persistent tendency of a time series to move in any direction is secular trend. There are yearly movements tending to move upward for some succeeding years over the entire period is cyclical variations. If the data are recorded over months, there are monthly variations taking place in individual years. These monthly variations are known as seasonal variations. Finally there may be abrupt, but not frequent, variations that go extremely deep downward or very high upward. These are called irregular variation.

\section{Trend Values By Least Square Method}

A straight line trend is, however more frequently encountered because most business and economic time series either consistently tends to increase or decreases over a period. Once a straight line is fitted, a trend equation $\mathrm{Tt}=\mathrm{a}+\mathrm{bX}$. Where $\mathrm{a}$ and $\mathrm{b}$ are constants. To obtain definite values from the above equation fitting a straight line trend by least square method.

The equation of a straight line is $\mathrm{Y}_{\mathrm{c}}=\mathrm{a}+\mathrm{bX}$

When $X=0$, Value of $a=20320.18$; Value of $b=118$

Hence, the trend line is $Y_{c}=20320.18+118 X$

To find out the trend values or computed values of $Y$ form different values of $X$, for the year 2001 the value of $X=-5$

We substitute the value of $\mathrm{X}$ in the above equation and get the following results.

When $\mathrm{X}=-5 \mathrm{Y}_{\mathrm{c}}=20320.18+(-5 \times 118)=20910.18$

Similarly, other values are calculated,

We get the trend values for the year 2001 to 2011 by substituting the value of $X$, from these computed values we can get a straight trend line as given in table 2 .

\subsection{Tea Import}

\section{Findings Of The Study}

During 2001 the quantum of tea imported was $17.1 \mathrm{M} . \mathrm{Kgs}$ and at the unit value of Rs. 55.50 and in 2011, the import of tea rose to 18.6 M.Kgs at the unit value of Rs. 92.84 in the year 2011, Nepal and Kenya turned to be the major source of the higher unit value of imports from these two countries. During 2011, the quantum of imports has declined to $18.6 \mathrm{M} . \mathrm{Kgs}$ compared to $20.0 \mathrm{M} . \mathrm{Kgs}$, a decline of 1.4 M.Kgs.

\subsection{Tea Production}

World tea production in the year 2010 was 4162.53 M.Kgs compared to 3944.38 M.Kgs reported in the previous years, an increase of 218.15 M.Kgs. the total tea production of India in the year 1996, was 780.1 M.Kgs, and in the year 2010, the production increased to 996.40 M.Kgs. In the year 1996, domestic tea production in South India was 182.0 M.Kgs and an increase of 598.1 M.Kgs in North India. In the year 2010, the domestic tea production in Tamilnadu, Kerala and Karnataka was 170.7 M.Kgs, 66.8 M.Kgs and 5.9 M.Kgs. In 2010, North India tea production was 723.0 M.Kgs.

\subsection{Tea price}

In the year 1996, South India tea auction price at Cochin was Rs 44.42 Coimbatore tea price was Rs 41.30 and Coonoor tea price was Rs 38.40; in the year 2010, tea price at Cochin was Rs 77.45, Coimbatore tea price was Rs 63.49 and Coonoor tea price was Rs 61.11. In the year 1996, North India tea price at Kolkatta was Rs 58.76, Guwahati tea price was Rs 50.13, Siliguri tea price was Rs 47.73 and in Amristar tea price was 
Rs.29.54, During the year 2010, tea price increased in Kolkatta to Rs 132.97, in Guwahati an increase of Rs 112.93, Siliguri and Amristar there was an increase of Rs 104.44 and Rs.109.25 in various tea auction centres.

\section{Suggestion And Measures}

- Government or tea organization must give proper information to the farmers and manufacture to increase tea production.

- Government has to reduce various taxes levied for tea and subsidies bring the change in tea production and price level.

- Proper maintenance of factories and the tea production to be in hygienic process.

- Regular maintenance of tea estates by using fertilizer, pesticide and organic manure bring an increase in tea production.

- Natural climate brings the fluctuation in tea production, so manufacture has to sustain the tea production by adopting various precaution measures.

- Quality control department must have a regular inspection to the factories to maintain good quality of tea to be produced.

- Farmers and Manufactures have to reduce the cost of cultivation and cost of production.

- Consumer must be motivated to consume herbal tea, which is a healthy drink and increase tea sales in domestic market and international market.

- Government must have intervention in the tea export and to get a fair price for agriculturists and no intermediaries are to be involved in tea exports.

XII. Tea Imports of India

Table: 1

\begin{tabular}{|c|c|c|}
\hline Year & Tea Imports (Th.Kgs) & Unit Value (Rs/Kgs) \\
\hline 2001 & 17180 & 55.50 \\
\hline 2002 & 24800 & 46.30 \\
\hline 2003 & 9860 & 58.33 \\
\hline 2004 & 30800 & 45.88 \\
\hline 2005 & 16713 & 58.62 \\
\hline 2006 & 23810 & 50.15 \\
\hline 2007 & 15987 & 65.43 \\
\hline 2008 & 20272 & 79.90 \\
\hline 2009 & 25460 & 84.23 \\
\hline 2010 & 20040 & 92.26 \\
\hline 2011 & 18600 & 92.84 \\
\hline \multicolumn{2}{|l}{} \\
\hline Source: Tea Statistics & \multicolumn{2}{|}{} \\
\hline
\end{tabular}

XIII. Computed Value of Tea Imports in India

Table: 2

\begin{tabular}{|c|c|c|}
\hline Year & Actual Value & Computed Value \\
\hline 2001 & 17180 & 19730.18 \\
\hline 2002 & 24800 & 19848.18 \\
\hline 2003 & 9860 & 19966.18 \\
\hline 2004 & 30800 & 20084.18 \\
\hline 2005 & 16713 & 20202.18 \\
\hline 2006 & 23810 & 20320.18 \\
\hline 2007 & 15987 & 20438.18 \\
\hline 2008 & 20272 & 20556.18 \\
\hline 2009 & 25460 & 20674.18 \\
\hline 2010 & 20040 & 20792.18 \\
\hline 2011 & 18600 & 20910.18 \\
\hline
\end{tabular}




\section{Conclusion}

Increase in export business helps in earning scarce foreign exchange and stimulate the domestic industry to manufacture the qualitative products for the world market. In India the tea leaves production varies according to the region and natural climate, such as over production or low production and quality wise the tea price differ. We have different price level in north India and south India. Though we have to adopt various technologies to increases production and to control the tea price fluctuation, in 2010, India earns foreign exchange from exporting tea is Rs.3058.3crores. Government must interfere to fix fair price without any intermediates and take necessary measures to increase in exporting quality tea. In 2009-2010 share of agriculture and allied sector contributes 14.6 percent of India's GDP. Though natural climate brings the fluctuation in tea production, Government have to implement the appropriate EXIM policy to increase the quantity of tea export and reduce the quantity of tea import.

\section{References}

[1] Elhance, D N. VeenaElhance and Aggarwal, B.N, Fundamental of statistics (Allahabad, KitabMahal, 2011).

[2] Gaurav Datt, Ashwani Mahajan, Datt and sundaram, Indian economy, (New Delhi, S.Chand and Company Ltd, 2011).

[3] Grewal, P.S, Methods of stastistical analysis, (New Delhi, Sterling Publishing Private Ltd, 1990)

[4] Gupta, S.P, Statistical methods, (Delhi, Sulthan Chand and Sons 2008).

[5] Hooda, R P, Statistics for business and economics, (New Delhi, Macmillan, 2000).

[6] Kothari, C R, Research methodology methods and techniques, (New Delhi, Wilsey Eastern Limited, 1992).

[7] RuddarDatt Sundharam K.P.M, Indian economy, (New Delhi, Chan and Company Ltd, 2009).

[8] Year book and Annual report, (United Planters Association of South India, Coonoor, 2011).

[9] http//www.tea board.gov.in

[10] http//www.UPASI.org. 